\title{
Physical development and physical preparedness monitoring of lyceum students of different ages
}

\author{
Popel S.L. ${ }^{1 \mathrm{ABCD}}$, Faychak R.I. ${ }^{1}{ }^{\mathrm{ACD}}$, Tcap I.G. ${ }^{1}{ }^{\mathrm{ACD}}$, Bejga P.M. ${ }^{2}$ ACD , Lysenko Y.O. ${ }^{3 \mathrm{ACD}}$, \\ Śliwiński Z. ${ }^{4 A C D}$ \\ ${ }^{1}$ Vasil Stefanyk Precarpatian National University, Ivano-Frankivsk, Ukranian \\ ${ }^{2}$ Elena Gura, Poland \\ ${ }^{3}$ Independent Public Healthcare team in Zgorzelec, Poland \\ ${ }^{4}$ Jan Kochanowski University, Poland
}

Authors' Contribution: A - Study design; B - Data collection; C - Statistical analysis; D - Manuscript Preparation; E - Funds Collection

Corresponding author: Serhii Popel, ORCID: 00001-9019-3966, Shevchenko str. 57, 76025, IvanoFrankivsk, popelsergij@gmail.com

DOI: https://doi.org/10.34142/HSR.2021.07.04.09

How to Cite

Popel SI, Faychak RI, Tcap IG, Bejga PM, Lysenko YO, Śliwiński Z. Monitoring of physical development and physical preparedness of lyceumists of different ages. Health, Sport, Rehabilitation. 2021;7(4):111-118. https://doi.org/10.34142/HSR.2021.07.04.09

\begin{abstract}
Purpose: to analyze the results of monitoring the physical development and physical preparedness of students of the Lyceum

Materials and methods: The analysis of materials on this issue was carried out based on the results of the implementation of the national educational initiative "Our New School" in accordance with the plan for the modernization of general education [3], according to which in 2019-2020 in secondary schools of Ivano-Frankivsk, the physical development of schoolchildren and schoolgirls was monitored 100 lyceum students 11-17 years old were examined, who were divided into 2 groups according to their academic performance: 1 gr. consisted of 50 lyceum students ( 35 girls and 15 boys) with high academic performance (average score 4.75), in the composition of $2 \mathrm{gr}$. it included 50 lyceum students - "lagging behind" (average score 3.5) ( 25 girls and 25 boys).

Results: monitoring showed that, regardless of the group, lyceum students have an average level of physical development (girls $-62.1 \%$, boys - $57.8 \%$ ). Only $13.8 \%$ of girls and $14.4 \%$ of boys have a high level of physical development. Almost a quarter of high school students (23.9\% of girls and $27.5 \%$ of boys) have a low level of physical development, and there are almost 2 times more such students than lyceum students with a high level of physical development.

Conclusion: Summarizing the above, it should be noted that when implementing the results of monitoring physical development, there are two main directions: 1 . Correction of deviations identified during monitoring in the state of development of physical condition. 2. Using student monitoring as a basis for creating a sports selection system. Based on this, we can conclude that an important component and subject of monitoring is the physical health of lyceum students, mainly in educational institutions, which contributes to monitoring and management decisions on making adjustments to the educational process.

Key words: physical development, lyceum students, physical training
\end{abstract}

(C) Popel S.I., Faychak R.I., Tcap I.G., Bejga P.M.,

Lysenko Y.O., Śliwiński Z., 2021.

https://doi.org/10.34142/HSR.2021.07.04.09 


\title{
Анотація
}

Сергій Л. Попель, Роман І. Файчак, Ірина Г. Цап, Пшемислав Бежга, Юрій А. Лисенко, Збігнєв Слівінський. Моніторинг фізичного розвитку і фізичної підготовленості ліцеїстів різного віку

Мета: проаналізувати результати моніторингу фізичного розвитку та фізичної підготовленості студентів ліцею Матеріал і методи: Аналіз матеріалів з даної проблеми проводився за результатами реалізації національної освітньої ініціативи «Наша Нова школа» відповідно до плану модернізації загальної освіти [3], згідно з яким в 2019-2020 рр. у загальноосвітніх школах Івано-Франківська проводився моніторинг фізичного розвитку школярів і школярок. Обстежено 100 ліцеїстів 11-17 років, які по успішності були розділені на 2 групи: 1 гр. складалася з 50 ліцеїстів (35 дівчаток і 15 хлопчиків) з високою успішністю (середній бал 4,75), в складі 2 гр. в нього увійшли 50 ліцеїстів-«відстаючих» (середній бал 3,5) (25 дівчаток і 25 хлопчиків). Результати: моніторинг показав, що незалежно від групи у ліцеїстів середній рівень фізичного розвитку (дівчатка - 62,1\%, хлопчики - 57,8\%). Лише 13,8\% дівчаток і 14,4\% хлопчиків мають високий рівень фізичного розвитку. Майже чверть старшокласників (23,9\% дівчаток і 27,5\% хлопчиків) мають низький рівень фізичного розвитку, а таких ліцеїстів майже в 2 рази більше, ніж ліцеїстів з високим рівнем фізичного розвитку.

Висновок: Резюмуючи вищевикладене, слід зазначити, що при реалізації результатів моніторингу фізичного розвитку виділяють два основних напрямки: 1. Корекція відхилень, виявлених в ході моніторингу, в стані розвитку фізичного стану. 2. Використання моніторингу студентів як основи для створення системи спортивного відбору. Виходячи з цього, можна зробити висновок, що важливою складовою і предметом моніторингу $є$ фізичне здоров'я ліцеїстів, в основному в освітніх установах, що сприяє моніторингу та управлінським рішенням щодо внесення коригувань в навчальний процес.

Ключові слова: фізичний розвиток, ліцеїсти, фізична підготовка

\begin{abstract}
Аннотация
Сергей Л. Попель, Роман И. Файчак, Ирина Г. Цап, Пшемислав Бежга, Юрий А. Лисенко, Збигнев Сливинский. Мониторинг физического развития и физической подготовленности лицеистов разного возраста

Цель: проанализировать результаты мониторинга физического развития и физической подготовленности студентов лицея

Материал и методы: Анализ материалов по данной проблеме проводился по результатам реализации национальной образовательной инициативы «Наша Новая школа» в соответствии с планом модернизации общего образования, согласно которому в 2019-2020 гг. в общеобразовательных школах Ивано-Франковска проводился мониторинг физического развития школьников и школьниц. Обследовано 100 лицеистов 11-17 лет, которые по успеваемости были разделены на 2 группы: 1 гр. состояла из 50 лицеистов (35 девочек и 15 мальчиков) с высокой успеваемостью (средний балл 4,75), в составе 2 гр. в него вошли 50 лицеистов«отстающих» (средний балл 3,5) (25 девочек и 25 мальчиков).

Результаты: мониторинг показал, что независимо от группы у лицеистов средний уровень физического развития (девочки - 62,1\%, мальчики - 57,8\%). Лишь 13,8\% девочек и 14,4\% мальчиков имеют высокий уровень физического развития. Почти четверть старшеклассников (23,9\% девочек и 27,5\% мальчиков) имеют низкий уровень физического развития, а таких лицеистов почти в 2 раза больше, чем лицеистов с высоким уровнем физического развития.

Вывод: Резюмируя вышеизложенное, следует отметить, что при реализации результатов мониторинга физического развития выделяют два основных направления: 1. Коррекция отклонений, выявленных в ходе мониторинга, в состоянии развития физического состояния. 2. Использование мониторинга студентов как основы для создания системы спортивного отбора. Исходя из этого, можно сделать вывод, что важной составляющей и предметом мониторинга является физическое здоровье лицеистов, в основном в образовательных учреждениях, что способствует мониторингу и управленческим решениям по внесению корректировок в учебный процесс.

Ключевые слова: физическое развитие, лицеисты, физическая подготовка
\end{abstract}




\section{Introduction}

In recent years, the situation with the health of the population in Ukraine has worsened. According to statistics, $50 \%$ of children have poor health, $75 \%$ of children under the age of 14 have chronic diseases, only $10 \%$ of school graduates can be called healthy. The overall incidence of children under 14 years of age increased by $16 \%$, at the age of 15-17 years - by $18 \%$. Against this background, the level of physical development of children decreases [1]. The current provision has updated the work on the implementation of monitoring research in various fields of activity and at various levels, including in the field of physical culture and sports in order to increase the efficiency of the process of physical education of schoolchildren. Adolescent physical development monitoring is a complex information-analytical and prognostically important system that includes monitoring of health and physical development and its assessment along with analysis at the level of an individual or social group, in order to predict future health both for the individual and for the whole group of persons united on a territorial basis or nature of activity. Such monitoring allows to prevent negative tendencies of physical development of children and adolescents [2].

Purpose: to analyze the results of monitoring of physical development of lyceum students of technical and mathematical lyceum № 2 in Ivano-Frankivsk, Ukraine.

\section{Materials and methods}

The analysis of materials on this issue was conducted based on the results of the implementation of the national educational initiative "Our New School" in accordance with the plan of modernization of general education [3] according to which in 2019-2020. Ivano-Frankivsk secondary schools monitored physical development and schoolchildren. 100 lyceum students aged 11-17 years were examined, who were divided into 2 groups according to the level of success: 1 gr. consisted of 50 lyceum students ( 35 girls and 15 boys) with a high level of success (average grade point average 4.75), consisting of 2 gr. included 50 "failing" lyceum students (average grade point average 3.5 ) (25 girls and 25 boys).

\section{Results}

Results of the monitoring showed that regardless of the group, lyceum students have an average level of physical development (girls - 62.1\%, boys $57.8 \%$ ). Only $13.8 \%$ of girls and $14.4 \%$ of boys have a high level of physical development. Almost a quarter of high school students $(23.9 \%$ of girls and $27.5 \%$ of boys) have low levels of physical development and such lyceum students are almost 2 times more than lyceum students with a high level of physical development.

The monitoring revealed intergroup differences in the indicators of physical development lyceum students, which belong to different success groups. Thus, the high level of physical development girls 1 group is higher than 2 group. The boys have 2 group this figure is lower than the boys 1 group.

Number of lyceum students 2 group with an average level of physical development, more than their peers 1 group. It should be noted that high school students 2 group with a low level of physical development is observed in more than 1 group. Analysis of the dynamics of the level of physical development by individual educational indicators shows a sharp decline in the number of lyceum students with an average level of physical development and on increasing the number of lyceum students with low levels of physical development in the transition from one age group to another

In the senior school age the indicator of low level of physical development is more often found at girls. It was found that almost $26 \%$ more girls with an average level of physical development. Boys of senior school age with a low level of physical development are 2.5 times more than boys of primary school age.

Physical development is an important indicator of human health, the close relationship between them, scientists have long observed [4]. The purpose of monitoring physical development is to obtain the information necessary to improve the management of the process of physical education, and thus improve its quality. Among the main conditional physical qualities, which were monitored, include speed, endurance, and strength. The analysis of indicators of physical development of lyceum students allowed to state low indicators of level of development of separate physical qualities (fig. 5), especially endurance. In general, in the lyceum in all age groups, lyceum students meet the age standards for strength and speedpower qualities. At the same time at girls indicators 
of endurance and force qualities ( $3.3 \pm 0.12$ and 4.1 \pm 0.14 points accordingly) are higher, than at boys $(2.9 \pm 0.11$ and $3.5 \pm 0.13$ points in accordance).

\section{Discussion}

Physical training of lyceum students at all stages of education should be aimed at strengthening health, developing motor skills and abilities, fostering moral and volitional qualities, developing the ability to use and introduce the knowledge gained into the practice of further professional activity. The found ratios of physical training of lyceum students established by us confirm the data of other authors [5-9] on the age characteristics of the development of individual physical qualities necessary for the harmonious development of the body of adolescents of 6-17 years old. Thus, the results of monitoring allow to state the insufficient level of physical fitness of lyceum students (first of all those qualities that determine the state of physical health). We can agree with the opinion of [4] that the reason for this situation is not so much the material and technical base of the educational institution, as the professional qualities of a physical education teacher, evidence of this is the fact that within one school, the performance of students who are engaged in different teachers, differ significantly. Thus, the study allows us to make the following generalizations. The pedagogical heritage of $\mathrm{R}$. Steiner [16] contains many important healthy theoretical provisions, the implementation of which will contribute to the effectiveness of health care in the modern educational process. First of all, it concerns the need to focus school activities on human nature and identify special care for the preservation and development of personal potential and abilities of the child, so that the school process as a necessary and mandatory component is filled with "therapeutic", ie aimed at spiritual and mental -body health aspect [10 - 15]. We see prospects for further research in the analysis of the implementation of healthy ideas of [16] in the practice of modern lyceums. As [16] emphasizes, an important aspect of the educational process is the personality-oriented formation of the child's personality, which involves taking into account the age and individual characteristics of the child, his current condition. In order to implement these requirements, R. Steiner developed specific forms and methods of teaching, namely: rhythmic construction of school classes, teaching basic subjects in cycles of "immersion" (the method of "epochs"), differentiation of educational material according to students' temperaments, learning without standard textbooks, specific methods of work of schoolchildren with workbooks, special work on the technique of memorization, systematic control over learning outcomes without the use of a grading system. As [16] emphasizes, an important aspect of the educational process is the personality-oriented formation of the child's personality, which involves taking into account the age and individual characteristics of the child, his current condition. In order to implement these requirements, [16] developed specific forms and methods of teaching, namely: rhythmic construction of school classes, teaching basic subjects in cycles of "immersion" (the method of "epochs"), differentiation of educational material according to students' temperaments, learning without standard textbooks, specific methods of work of schoolchildren with workbooks, special work on the technique of memorization, systematic control over learning outcomes without the use of a grading system. Therefore, in order to maintain the proper physical and functional condition of female lyceum students, and at the same time fulfill the requirements of the departmental order in this regard, we propose to include in the training elements of the program of special physical training based on the modular education system [17-20].

\section{Conclusion}

Summarizing the above, it should be noted that in the implementation of the results of monitoring of physical development there are two main areas: 1. Correction of abnormalities identified during the monitoring in the state of development of physical condition. 2. The use of monitoring of students as a basis for creating a system of sports selection. Based on this, we can conclude that an important component and subject of monitoring is the physical health of lyceum students, mostly in educational institutions, which facilitates monitoring and management decisions to make adjustments to the educational process.

\section{Conflict of interest}

The authors declare that there is no conflict of interest. 


\section{References}

1. Korobeynikov G, Potop V, Korobeynikova L, Kolumbet A, Khmelnitska I, Shtanagey D, Mischenko V, Aksutin V, Goletc A. Research of the hand motion dynamic characteristics of the women boxers with different types of functional asymmetry. Journal of Physical Education and Sport. 2019;19:2185-2191. doi:10.7752/jpes.2019.s6328.

2. Yagotin RS, Degtyarenko TV, Bosenko AI, Plisko VI, Dolinsky BT. Criterion score of the physical and psychophysiological condition of students in the context of determining their individual adaptability to physical loads. Physical education of students. 2019(1):51-7. doi:10.15561/20755279.2019.0108.

3. Görner K, Reineke A. The influence of endurance and strength training on body composition and physical fitness in female students. Journal of Physical Education and Sport. 2020;20;3;272:2013-2020. doi:10.7752/jpes.2020.s3272.

4. Kokun O, Imas Y, Vovkohon A, Potop V, Korobeynikov G, Korobeynikova L, PolevayaSecaryanu A. Physical education and sports as a tool for formation of students' psychophysiological readiness to their professional work. Journal of Physical Education and Sport. 2018;18(2):966-971. doi:10.7752/jpes.2018.02143.

5. Korobeynikov G, Glazyrin I, Potop V, Archipenko V, Glazyrina V, Dudnyk O, Korobeinikova L, Dakal N. Adaptation to endurance load in youths. Journal of Physical Education and Sport. 2019;19:1035-1040. doi:10.7752/jpes.2019.s3149.

6. Kovalenko A, Grishchuk E, Rogal N, Potop V, Korobeynikov G, Glazyrin I, Glazyrina V, Goraşcenco A, Korobeynikova L, Dudnyk O. The Influence of Physical Activity on Students' Psychological Well-Being. Revista Romaneasca pentru Educatie Multidimensionala. 2020;12(2):8696. doi:10.18662/rrem/12.2/267.

7. Popov PN, Manaev IO. Stanovleniye sistemy proverki i otsenki fizicheskoy podgotovki v rukovodyashchikh dokumentakh, reglamentiruyushchikh fizicheskuyu podgotovku uchashchikhsya. Studencheskiy vestnik [Establishment of a system of verification and assessment of physical fitness in the guidance documents regulating the physical fitness of students]. Student bulletin. 2021;1-2 (146): 32-35. [in Russian]

8. Muravyov AV, Odintsova TK. Obshchaya fizicheskaya podgotovka kak sostavlyayushchaya professional'noprikladnoy fizicheskoy podgotovki kursantov obrazovatel'nykh organizatsiy Penitentsiarnoye pravo: yuridicheskaya teoriya i practica [General physical training as a component of professionally applied physical training of cadets of educational organizations Penitentiary law: legal theory and law enforcement practice]. 2020; 2 (24): 29-32. [in Russian]
9. Kosheleva E. Osobennosti fizicheskogo vospitaniya litseistov [Features of physical training of lyceum students]. Physical culture, sport and health, 2021; 18. [in Russian]

10. Osipov A, Tselovalnikova M, Klimas N, Zhavner T, Vapaeva A, Mokrova T. Realization of Anti Gravity fitness exercises in physical education practice of female students. Journal of Physical Education and Sport. 2019;19;4;207:1429-1434. doi:10.7752/jpes.2019.s4207.

11. Pogrebniak IM, Kudelko VE, Nagovitsina OP. Effect of improving aerobics classes at the level of flexibility of female students. Pedagogics, Psychology, Medical-Biological Problems of Physical Training and Sports. 2013;5:49-52.

12. Korobeynikov GV, Mishko VV, Korobeinikova LG. Factor structure of manifestation of success in the formation of choreographic skills in young dancers. Health, sport, rehabilitation. 2020;6(1):26-31. doi:10.34142/HSR.2020.06.01.03.

13. Beltrán-Velasco AI, Ruisoto-Palomera P, BellidoEsteban A, García-Mateos M, Clemente-Suárez VJ. Analysis of psychophysiological stress response in higher education students undergoing clinical practice evaluation. Journal of medical systems. 2019 Mar;43(3):1-7. doi:10.1007/s10916-019-1187-7.

14. (Rovniy Trushkova) Kokun O, Korobeynikov G, Mytskan B, Cynarski WJ. Applied aspects of improving pupils' and students' adaptive capacity. Ido Movement for Culture. Journal of Martial Arts Anthropology. 2019;19(3):38-45. doi: 10.14589/ido.19.3.5.

15. Hakman A, Andrieieva O, Kashuba V, Nakonechnyi I, Cherednichenko S, Khrypko I, Tomilina Y, Filak F, Moldovan A. Characteristics of biogeometric profile of posture and quality of life of students during the process of physical education. Journal of Physical Education and Sport. 2020;20(1);10:79-85. doi:10.7752/jpes.2020.01010.

16. Podstawski R, Żurek P, Clark C, Ihash F, Kozina Z, Omelan A. Sex-mediated differences among university students performing extreme physical activity during the 3-minute burpee test. Polish Journal of Sport and Tourism. 2019;26(2):27-33. doi:10.2478/pjst-2019-0011.

17. Georgievich PG. The effect of coordination training on switching the attention of schoolchildren with different typologies. International Journal of Medical Research \& Health Sciences. 2019;8(6):151-6.

18. Kozina Z, Prusik K, Gorner K, et al. Comparative characteristics of psychophysiological indicators in the representatives of cyclic and game sports. Journal of Physical Education and Sport. 2017; 17(2);97:648655. doi:10.7752/jpes.2017.02097.

19. Kozina ZL, Iermakov SS. Analysis of students' nervous system's typological properties, in aspect of response to extreme situation, with the help of multidimensional analysis. Physical Education of Students. 2015;3:10-19. 
20. Kozina ZH, Korobeinik VI, Safronov DA, Xiaofei WA. Effect of the individual approach application during the training of future physical education teachers on the degree of student satisfaction with the learning process in the People's Republic of China. Journal of Physical Education and Sport. 2021;21(5):2524-31. doi:10.7752/jpes.2021.05339

\section{Serhii L.Popel}

\section{Information about authors}

popelsergij@gmail.com

http://orcid.org/00001-9019-3966

prof. department physical culture and sport

Vasil Stefanyk Precarpatian University,

Shevchenko str. 57, 76025, Ivano-Frankivsk, Ukraine

\section{Roman I. Faychak}

romfay@meta.ua

http://orcid.org/0000-0001-9082-1213

Department of Physical Education

Vasyl Stefanyk Precarpathian National University,

Shevchenko str. 57, 76025, Ivano-Frankivsk, Ukraine

\section{Irina G. Tcap}

tsapiryna3@gmail.com

https://orcid.org/0000-0002-9698-0255

Assistant of Department of sports pedagogical disciplines

Vasyl Stefanyk Precarpathian National University,

Shevchenko str. 57, 76025, Ivano-Frankivsk, Ukraine

Przemek M. Bejga

popelsergij@gmail.com

https://orcid.org/0000-0003-4871-4689

Wroclaw medical University,

Wybrzeże L. Pasteura 1, 50-367 Wrocław, Poland

Yury O. Lysenko

popelsergij@gmail.com

orcid.org/0000-0002-2161-535X

WS- SamodzielnyPubliczny (Polska)

Zespol opieki zdrowotnej w zgorzelcu ul. Lubanska

11-12 59-900 Zgorzelec Nip 615-17-06-942, Regon: 231161448

Stacjonarny Osrodek Rehabilitacji Chorob

Naradu Ruchu dla Doroslych I dzieci

Im. Prof. Degi w Zgorzelcu, Poland

\section{Zbigniew Śliwiński}

popelsergij@gmail.com

https://orcid.org/0000-0001-7402-1793

WS- SamodzielnyPubliczny (Polska)

Zespol opieki zdrowotnej w zgorzelcu ul. Lubanska

11-12 59-900 Zgorzelec Nip 615-17-06-942, Regon: 231161448

Stacjonarny Osrodek Rehabilitacji Chorob

Naradu Ruchu dla Doroslych I dzieci Im. Prof. Degi w Zgorzelcu, Poland

\section{Сергій Л.Попель}

\section{Інформація про авторів}

popelsergij@gmail.com

http://orcid.org/00001-9019-3966

проф. кафедра фізичної культури і спорту

Прикарпатський університет імені Василя Стефаника, вул. Шевченка 57, 76025, м. Івано-Франківськ, Україна 
Роман І. Файчак

romfay@meta.ua

http://orcid.org/0000-0001-9082-1213

Кафедра фізичного виховання

Прикарпатський національний університет імені Василя Стефаника, вул. Шевченка 57, 76025, м. Івано-Франківськ, Україна

\section{Ірина Г. Цап}

tsapiryna3@gmail.com

https://orcid.org/0000-0002-9698-0255

Асистент кафедри спортивно-педагогічних дисциплін

Прикарпатський національний університет імені Василя Стефаника, вул. Шевченка 57, 76025, м. Івано-Франківськ, Україна

\section{Пшемек М. Бейга}

popelsergij@gmail.com

https://orcid.org/0000-0003-4871-4689

Вроцлавський медичний університет,

Wybrzeże L. Pasteura 1, 50-367 Wrocław, Poland

\section{Юрій О. Лисенко}

popelsergij@gmail.com

orcid.org/0000-0002-2161-535X

WS- незалежна громадськість (Польща)

Медична бригада у Згожелеці вул. Любанська

Стаціонарний центр реабілітації після хвороб,

Рада руху дорослих та дітей ім. Проф. Деги у Згожелеці,

11-12 59-900 Згорлек Нір 615-17-06-942, Регіон: 231161448

\section{Збігнєв Слівінський}

popelsergij@gmail.com

https://orcid.org/0000-0001-7402-1793

WS- незалежна громадськість (Польща)

Медична бригада у Згожелеці вул. Любанська

Стаціонарний центр реабілітації після хвороб,

Рада руху дорослих та дітей ім. Проф. Деги у Згожелеці,

11-12 59-900 Згорлек Нip 615-17-06-942, Регіон: 231161448

\section{Сергей Л. Попель}

\section{Информация об авторах}

popelsergij@gmail.com

http://orcid.org/00001-9019-3966

проф. кафедра физической культуры и спорта

Прикарпатский университет имени Василия Стефаника,

ул. Шевченко 57, 76025, Ивано-Франковск, Украина

\section{Роман И. Файчак}

romfay@meta.ua

http://orcid.org/0000-0001-9082-1213

Кафедра физического воспитания

Прикарпатский национальный университет имени Василия Стефаника, ул. Шевченко 57, 76025, Ивано-Франковск, Украина

\section{Ирина Г. Цап}

tsapiryna3@gmail.com

https://orcid.org/0000-0002-9698-0255

Ассистент кафедры спортивно-педагогических дисциплин

Прикарпатский национальный университет имени Василия Стефаника, ул. Шевченко 57, 76025, Ивано-Франковск, Украина 


\section{Пшемек М. Бейга}

popelsergij@gmail.com

https://orcid.org/0000-0003-4871-4689

Вроцлавский медицинский университет,

Wybrzeże L. Pasteura 1, 50-367 Вроцлав, Польша

\section{Юрий О. Лысенко}

popelsergij@gmail.com

orcid.org/0000-0002-2161-535X

WS- независимая общественность (Польша)

Медицинская бригада в Згожелеце ул. Любанская

Стационарный центр реабилитации после болезней,

Совет движения взрослых и детей им. Проф. Деги в Згожелеце,

11-12 59-900 Згорлек Нир 615-17-06-942, Регион: 231161448

\section{Збигнев Сливинский}

popelsergij@gmail.com

https://orcid.org/0000-0001-7402-1793

WS- независимая общественность (Польша)

Медицинская бригада в Згожелеце ул. Любанская

Стационарный центр реабилитации после болезней,

Совет движения взрослых и детей им. Проф. Деги в Згожелеце,

11-12 59-900 Згорлек Нир 615-17-06-942, Регион: 231161448

This work is licensed under a Creative Commons Attribution 4.0 International License (CC BY 4.0)

Received: 2021-12-09 Accepted: 2021-22-09 Published: 2021-25-12 